\title{
Phytoplankton community structure and it's relationships with water quality in Bangka Island, Indonesia
}

\author{
Muh Yusuf ${ }^{*}$, Robin Robin², Wahyu Adi3 ${ }^{3}$, Mu'alimah Hudatwi ${ }^{4}$, Widianingsih ${ }^{5}$, Retno Hartati ${ }^{5}$, \\ Robertus Triaji Mahendrajaya5, Cristiana Manullang 6
}

1Department of Oceanography, Faculty of Fisheries and Marine Sciences, Diponegoro University

Jl. Prof. Sudarto, SH, Tembalang, Semarang, Jawa Tengah, 50275 Indonesia

2Department of Aquaculture, Faculty of Agriculture, Fisheries and Biology, University of Bangka Belitung

Balunijuk Campus Centre, Merawang, Bangka, Bangka Belitung 33172, Indonesia

3 Department of Water Resource Management, Faculty of Agriculture Fisheries and Biology, University of Bangka Belitung Balunijuk Campus Centre, Merawang, Bangka, Bangka Belitung 33172, Indonesia

${ }^{4}$ Department of Marine Science, Faculty of Agriculture, Fisheries and Biology, University of Bangka Belitung

Balunijuk Campus Centre, Merawang, Bangka, Bangka Belitung 33172, Indonesia

${ }^{5}$ Department of Marine Science, Faculty of Fisheries and Marine Sciences, Diponegoro University

Jl. Prof. Sudarto, SH, Tembalang, Semarang, Jawa Tengah, 50275 Indonesia

${ }^{6}$ Graduate School of Engineering and Science, University of the Ryukyus

Nishihara, Okinawa, Japan

Email: yusuff.undip@gmail.com

\begin{abstract}
Phytoplankton plays an important role in primary productivity in marine environment. Various environmental changes in coastal area will impact the water quality and their phytoplankton compositions. The purpose of this study is to examine the abundance of phytoplankton from two different sites, i.e Tanah Merah (close to mining site) and Semujur Island (away from mining site) in Bangka Island. Phytoplankton and water sample were collected on June- August 2018. Water quality was measured using water quality checker, whereas the phytoplankton was identified under the microscope with a magnification of 100x. Non-parametric Kruskal test and T-test analysis was performed to determine the abundance, diversity, uniform, and dominance of phytoplankton between Sites, respectively. Statistical analyses showed the abundance of phytoplankton at Semujur Island was significantly higher than that at Tanah Merah $(p=0.003)$. In additions the diversity, uniform, and dominance were also significantly different between sites (all $p<0.05$ ). In Semujur Island, Diatoms (Thalassiothrix, Chaetoceros and Thalassionema) were more dominants than the Dinophyceae group. However, in Tanah Merah, the genera Ceratium belong to class Dinophyceae was more dominant than the class Bacillariophyceae. These results performed that the phytoplankton in Tanah Merah and Semujur Island was affected by environment, in this case the mining area. The water quality in Semujur Island (non-mining Area) might have good quality than in Tanah Merah (mining area). The average value of turbidity and Total Suspended Solid in Tanah Merah Waters causes low abundance of phytoplankton. It can be concluded that tin mining can disrupt the abundance and composition of phytoplankton as a primary producer of waters.
\end{abstract}

Keywords: Tin Mining, Phytoplankton, Tanah Merah, Semujur Island, Bangka, Indonesia

\section{Introduction}

Phytoplankton compositions are determined by environmental parameters and their physiological characteristics. Compositions and abundances of phytoplankton will change as a result to environmental variance conditions both physical, chemical, and biological (Reynolds et al., 2002). Several factors are controlling the phytoplankton distributions, such as marine physical process and nutrient inputs. Moreover, the change of water quality impacts of marine ecosystem included the composition of phytoplankton. (Nguyen and Nhien, 2020). The research on phytoplankton community response to these changes is useful to analize the hydrological variations in coastal waters (Troccoli et al., 2004). The water quality assessment by using biological material approach, such phytoplankton, will reflect changes caused by a decrease in quality a water. 
Bangka Belitung Islands Province has great tin potentials both in land and coastal areas. Mining activities are carried out from the plains to the coastal and marine areas. As the result of the heavy metal mining, it is inevitable that the occurrence of ecological damage on land to sea waters (Rachman, 2019). Exploitation of tin mining in coastal areas and oceans can cause toxin and waste. It causes low concentration of phosphate and nitrate, which are one of the limiting elements for water quality and ecosystem elements. (Lee and Jones-Lee, 2005; Haya, 2012).

Phosphate and nitrate have a vital role in the growth of phytoplankton and other aquatic plants, which are commonly used as indicators of water quality and productivity level in waters (Fachrul et al., 2005; Haya, 2012). The purpose of this study was to examine the abundance of phytoplankton in two different sites, which are Tanah Merah waters (as the mining site) and Semujur Island (away from the mining site).

\section{Material and Methods}

Phytoplankton sampling and water quality parameters were conducted in June, July, August 2018 in the Tanah Merah and Semujur Island, Bangka Belitung Islands. Tanah Merah Waters is close to the tin mining while Semujur Island Waters is far from tin mining (Figure 1.). Seawater's sampling was determined in 6 stations in each site, respectively.
Phytoplankton collection was taken vertically by using Kitahara nets (mesh size of $80 \mu \mathrm{m}$ ). Sea water measurement such as temperature, salinity, dissolved oxygen content was performed by using the water quality checker. Water samples for measurement of nitrate, phosphate, and TSS using Niskin bottle. Transparancy and depth measurements were carried out in situ. While water turbidity were measured by using turbidity meter.

Nitrate concentration analysis was
determined by Brusin method using spectrophotometer in $410 \mathrm{~nm}$ wavelength range. Meanwhile phosphate analysis was reducted using 0-1 mg.L-1 ascorbic acid and created phosphormolybdate complex that had a blue colour. The colour intensity as the result of the measurement has a similar concentration with phosphor. The identification was done by spectrophotometer in 700- $880 \mathrm{~nm}$ range.

Phytoplankton identification and calculation were carried out using the fraction method by transferring $1 \mathrm{ml}$ of the phytoplankton sample into the Sedgewick Rafter Counting Cell (SRCC). The identification was executed under a light microscope with a magnification of $100 x$ by using Sedgewick Rafter Counting Cell (SRCC). The identification was performed up to genus level based on Tomas (1997) and Yamaji (1979).

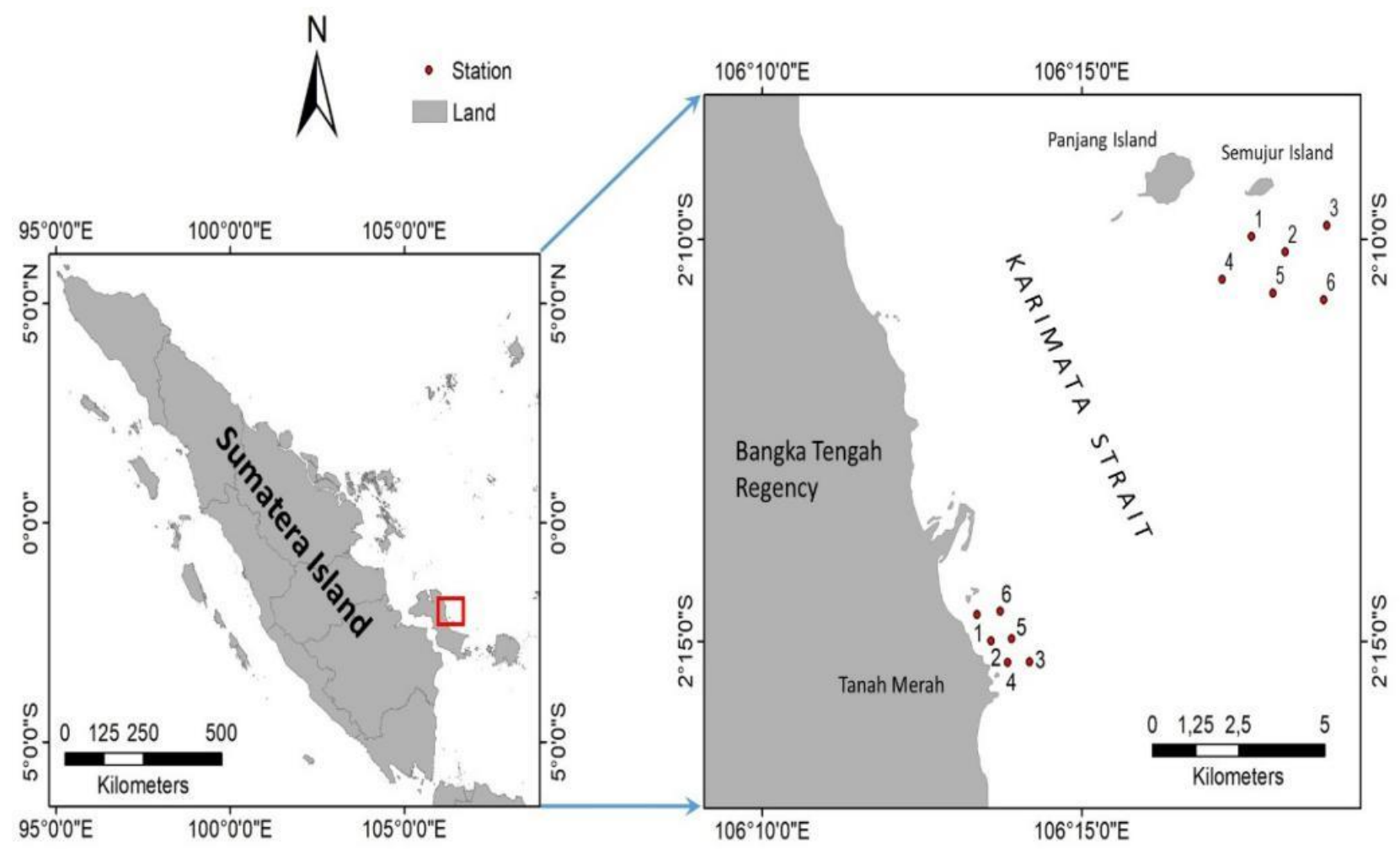

Figure 1. Location Sampling on Tanah Merah Waters and Semujur Island Waters 


\section{Data analysis}

The statistical analysis by non-parametric and parametric test was performed in this study. Kruskal-Wallis test is appropriate in cases in which the error distribution of a response variable is not normal (Zuur et al., 2009). T-test was carried out in case the data was normal and homogeny. The diversity index represents the condition of the ecosystem (Zaghloul et al., 2020). Diversity, Evenness and Dominance Indices were calculated based on Odum (1988). The analysis was conducted by using SPSS version 17, to determine the difference in abudance, diversity, uniform, and dominance of phytoplankton between Tanah Merah Waters and Semujur Island Waters.

\section{Result and Discussion}

\section{Phytoplankton abundance}

This study found that the abundance of phytoplankton in Semujur Island Waters was significantly higher than Tanah Merah ( $\alpha=0.01$; Figure 2). In Semujur Island Waters, the highest abundance of phytoplankton was found at station 4 that had abundance 318,000 cells.L-1 (Figure 2; Table 1 and 2). The range of average abundance values of Phytoplankton in Tanah Merah Waters was 182,000 - 200,000 cells. L-1 (Table 1; Figure 2). Besides, the range of the average value of phytoplankton abundance in Semujur Island Waters was $286,000-318,000$ cells.L-1 (Table 2; Figure 2).

By following the results, the classification system represented in the Tanah Merah Waters (mining area) and Semujur Island Waters (nonmining area) are included in the oligotrophic category because the abundance values in these two waters have an abundance of phytoplankton $<4.16 \times 10^{6}$ cells. L-1. (Spatharis and Tsirtsis, 2010)

The result of observations and data analysis shows the relative abundance (\%) of genera Ceratium was greater in Tanah Merah Waters than at the Semujur Island waters, and then followed by genera Thalassiothrix and Chaetoceros (Figure 3 and Table 1 and 2). Widianingsih et al. (2007) reported that at East Belitung Island Waters, there were many Ceratium and Rhizosolenia but Thalassiothrix is only found at one station. In non-mining and mining areas, Chaetoceros shows a considerable abundance at each station at the Bangka Waters (Rachman, 2019). On the other hand, the abundance Thalasiothrix was greater in Semujur Island Waters than in the Tanah Merah Waters, followed by Chaetoceros and Thalassionema (Table 1; Figure 3).

The abundance of diatoms in the Semujur Island Waters (non-mining area) was significantly higher than in Tanah Merah Waters (mining area), this case indicated that the seawater quality in Semujur Island Waters better than Tanah Merah Waters. The average value of the diversity index range at Semujur Island Waters ranges from 1.9712.229 (Figure 4.). This shows that Semujur Island Waters has more diverse phytoplankton than the Tanah Merah Waters. T-test shown that the diversity in Semujur Island was significantly higher than that in Tanah Merah (t-test, $p=0.009$ ), followed by uniform and dominance also were signifcanlty higher in Semujur Island than that in Tanah Merah (t.test, both $p=0.05$, respectively). The average value of the diversity index range at Semujur Island Waters ranges from 1.971-2.229 (Figure 4.). This shows that Semujur Island had more diverse phytoplankton than that in Tanah Merah.

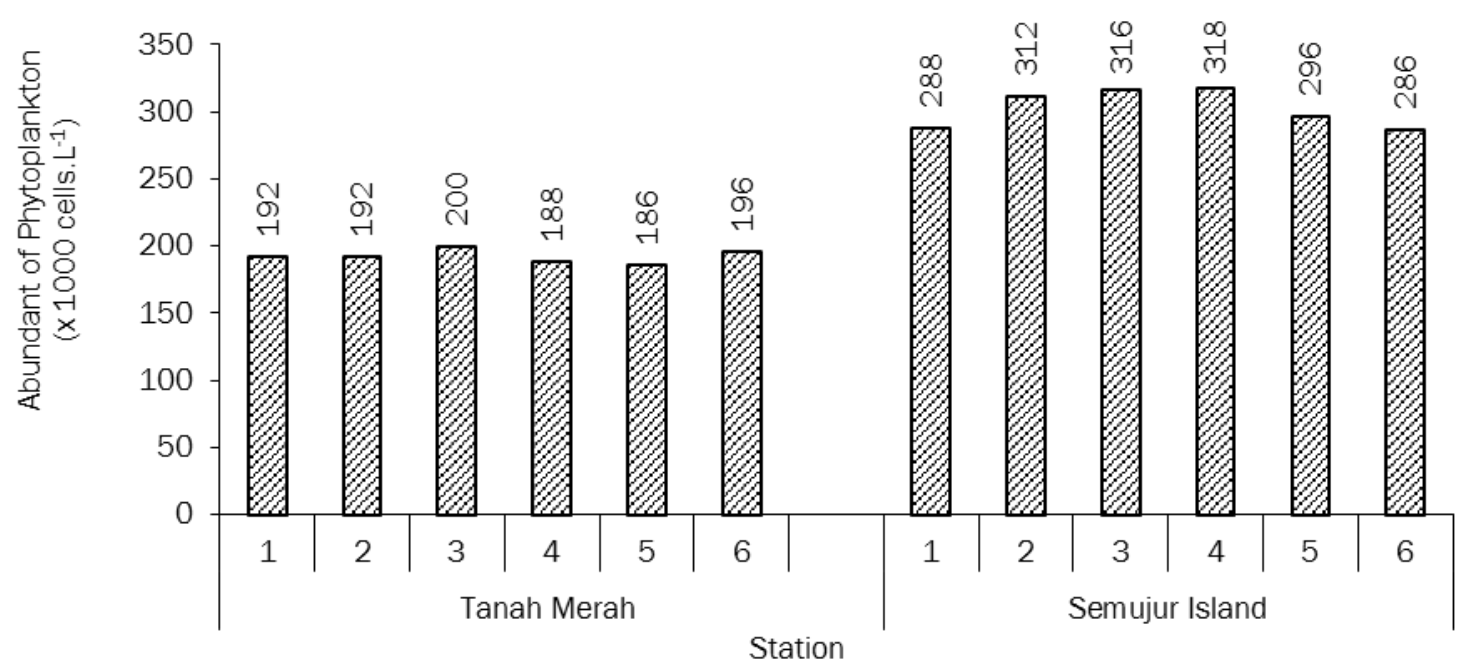

Figure 2. The Average of value abundant of Phytoplankton (x1000 cells. $\mathrm{L}^{-1}$ ) on Tanah Merah Waters and Semujur Island Waters 

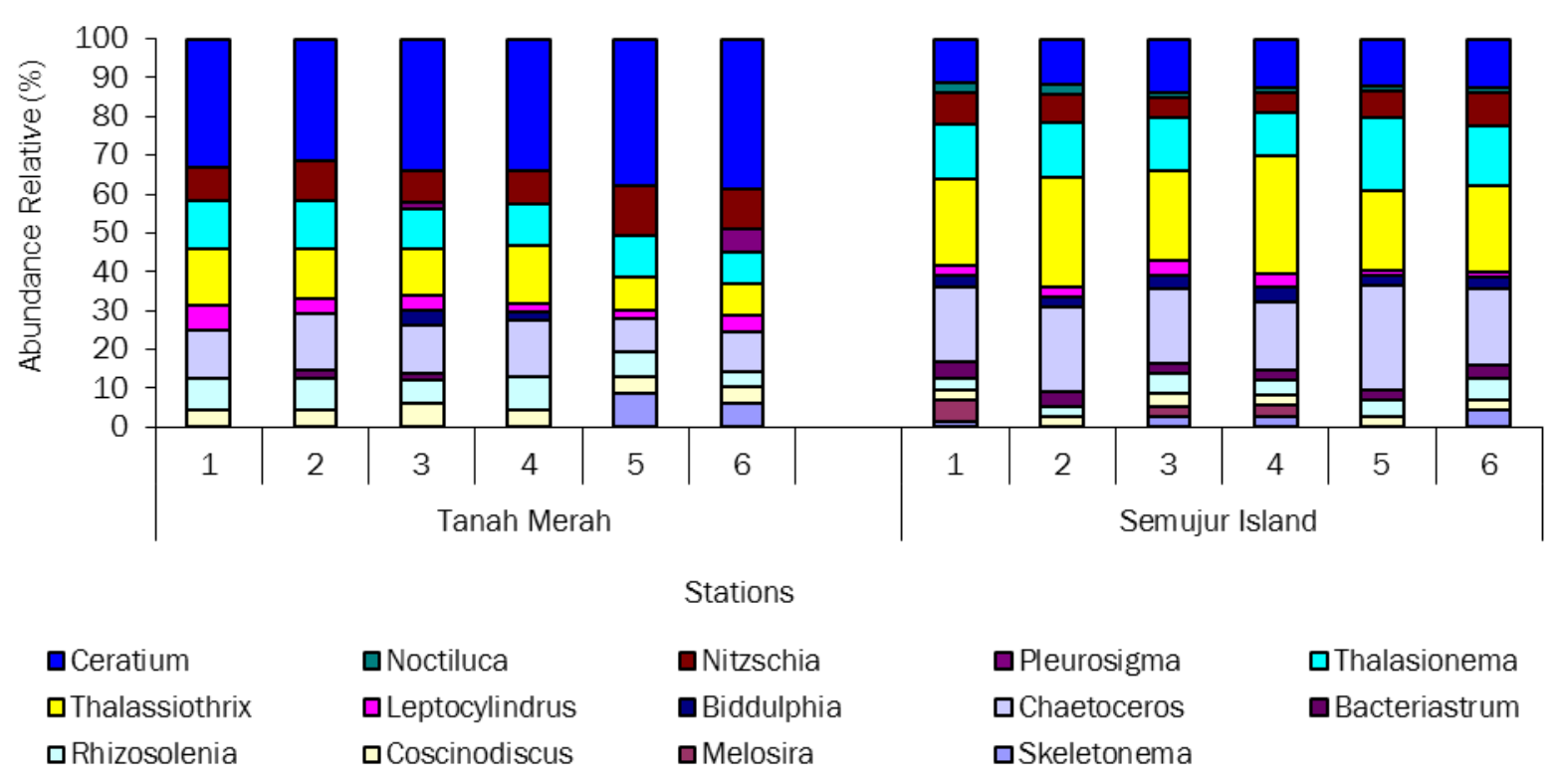

Figure 3. The Average of Relative Abundance (\%) Phytoplankton at Tanah Merah Waters and Semujur Island Waters

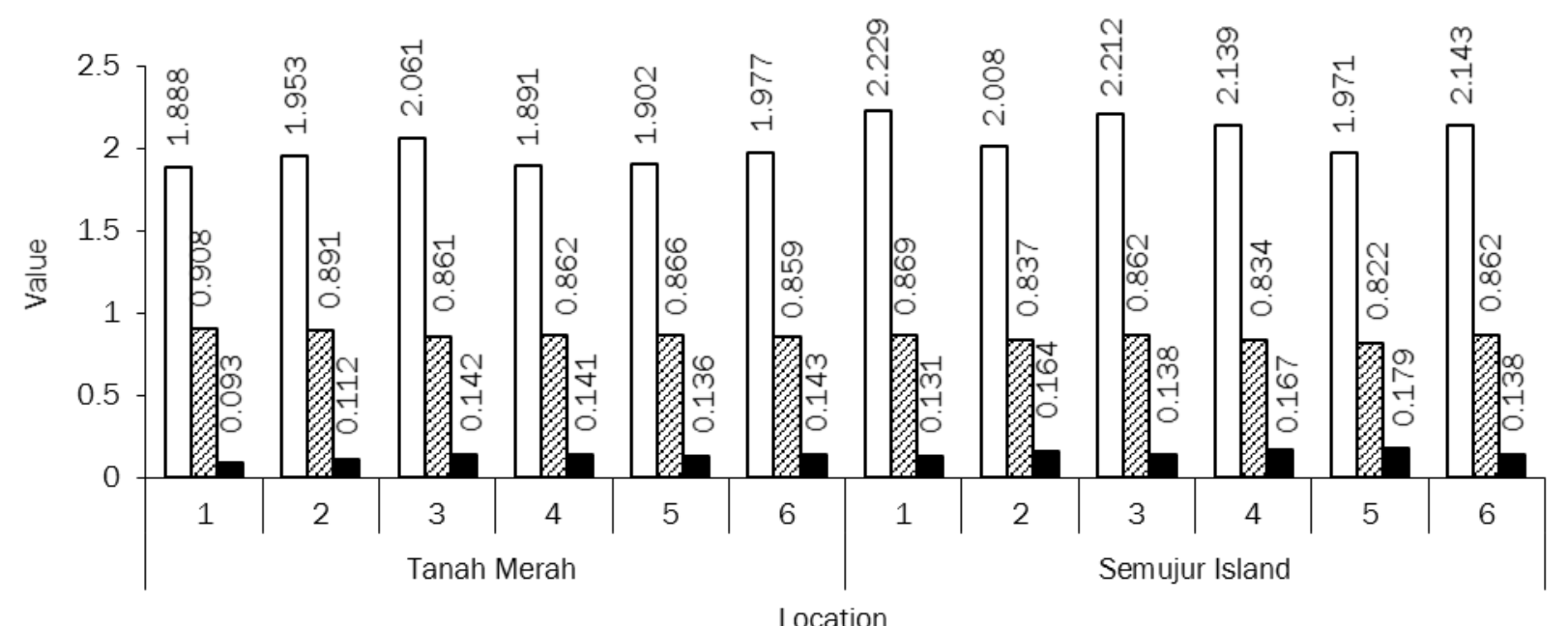

\section{口Series1 घSeries2 aSeries3}

Figure 4. The Average Value of Diversity Index, Evenness Index and Dominance Index from June, July and August 2018 in the Tanah Merah Waters and the Semujur Island Waters.

\section{Water quality parameter}

The seawater temperature during sample collection was significantly different between Sites (t-test, $P=0.02$ ). The temperature was consistent at $31^{\circ} \mathrm{C}$ in Tanah Merah while it more fluctuated in Semujur Island $\left(30-31^{\circ} \mathrm{C}\right)$. The temperature was colder in Semujur Island than that in Tanah Merah. Studies have revealed that phytoplankton growth depends on available sunlight, temperature, and nutrient levels. Cold temperature tends to have more nutrients than warm water, phytoplankton tends to be more plentiful where seawater was cold. Also, when surface seawater is cold, it is easier for deeper water to rise to the surface, bringing nutrients to sunlit areas where phytoplankton can use them. Range of salinity still suitable for phytoplankton growth.

The diffusion rate of $\mathrm{O}_{2}$ in sea water has been treated physical-chemically process. It is shown that although the activity of oxygen in the seawater remains constant when pressure $\mathrm{O}_{2}$ and temperature are constant (equilibrium conditions), the diffusion rate of oxygen will nevertheless vary proportionally to the solubility of oxygen in sea water, which decreases with increasing salinity (Millero and Sohn, 1992). 
ILMU KELAUTAN: Indonesian Journal of Marine Sciences March 2021 Vol 26(1):37-44

Table 1. Average of Abundance of Phytoplankton (cells.L-1) in the Tanah Merah Waters

\begin{tabular}{|c|c|c|c|c|c|c|c|}
\hline \multirow[b]{2}{*}{ No } & \multirow[b]{2}{*}{ Genera } & \multicolumn{6}{|c|}{ Station in Tanah Merah Waters } \\
\hline & & 1 & 2 & 3 & 4 & 5 & 6 \\
\hline 1 & Skeletonema & - & - & - & - & 16.000 & 12.000 \\
\hline 2 & Melosira & - & - & - & - & - & - \\
\hline 3 & Coscinodiscus & 8,000 & 8,000 & 12,000 & 8,000 & 8,000 & 8,000 \\
\hline 4 & Rhizosolenia & 16,000 & 16,000 & 12,000 & 16,000 & 12,000 & 8,000 \\
\hline 5 & Bacteriastrum & - & 4,000 & 4,000 & - & - & - \\
\hline 6 & Chaetoceros & 24,000 & 28,000 & 24,000 & 28,000 & 16,000 & 20,000 \\
\hline 7 & Biddulphia & - & - & 8,000 & 4,000 & - & - \\
\hline 8 & Leptocylindrus & 12,000 & 8,000 & 8,000 & 4,000 & 4,000 & 8,000 \\
\hline 9 & Thalasiothrix & 28,000 & 24,000 & 24,000 & 28,000 & 16,000 & 16,000 \\
\hline 10 & Thalasionema & 24,000 & 24,000 & 20,000 & 20,000 & 20,000 & 16,000 \\
\hline 11 & Pleurosigma & - & - & 4,000 & - & - & 12,000 \\
\hline 12 & Nitzschia & 16,000 & 20,000 & 16,000 & 16,000 & 24,000 & 20,000 \\
\hline 13 & Noctiluca & - & - & - & - & - & - \\
\hline 14 & Ceratium & 64,000 & 60,000 & 68,000 & 64,000 & 70,000 & 76,000 \\
\hline \multicolumn{2}{|c|}{ Total (cells.L-1) } & 192,000 & 192,000 & 200,000 & 188,000 & 186,000 & 196,000 \\
\hline
\end{tabular}

This is evidence that there is a relationship between salinity levels and DO content in marine waters.

Based on the results of DO measurements in June, July and August in the Semujur Island Waters, it has an average value of 6.87-6.96 ppm (Table 3). Whereas, at the Tanah Merah Waters, the measured DO average value are $6.59-6.89$ ppm. There is difference the mean of DO between Tanah Merah Waters (Mining Area) and Semujur Island Waters (t-test; one tail; t count $=4.778$; $\mathrm{df}=5$; $P=$ 0.05) (Table 4.). However, the DO values in both waters were still within normal levels. Dissolved oxygen is important role to many forms of life including fish, invertebrates, bacteria and others marine organisms. These organisms use oxygen in respiration. Phytoplankton require dissolved oxygen for respiration when there is no light for photosynthesis. The amount of dissolved oxygen needed varies from creature to creature. Bottom feeders, crabs, oysters and worms need minimal amounts of oxygen (1-6 mg. $\left.\mathrm{L}^{-1}\right)$, while shallow water fish need higher levels (4-15 mg. $\left.\mathrm{L}^{-1}\right)$.

Microbes such as bacteria and fungi also require dissolved oxygen. These organisms use DO to decompose organic material at the bottom of a body of water. Microbial decomposition is an important contributor to nutrient recycling. However, if there is an excess of decaying organic material (from dying algae and other organisms), in a body of water with infrequent or no turnover (also known as stratification), the oxygen at lower water levels will get used up quicker.

Likewise, the average $\mathrm{pH}$ value in Tanah Merah Waters has a range of 8.21-8.30 and at the
Semujur Island Waters are 8.31-8.39 (Table 3). The range of the average $\mathrm{pH}$ value in Semujur Island Waters is higher than Tanah Merah waters. Statistical test results show that there is difference the mean of $\mathrm{pH}$ value between Tanah Merah Waters and Semujur Island Waters (t-test one tail; $\mathrm{t}$ count = 6.751; df = 5; $P=0.05$ ) (Table 4.) The average $\mathrm{pH}$ value in the Semujur Island Waters is more alkaline than the average $\mathrm{pH}$ value in The Tanah Merah Waters. The average $\mathrm{pH}$ value in the Tanah Merah Waters and Semujur Island Waters is within normal limits. The average $\mathrm{pH}$ for sea water is 8.2 but can range between 7.5 and 8.5 depending on the local conditions. The average $\mathrm{pH}$ for sea water is 8.2 but can range between 7.5 and 8.5 depending on the local conditions (Dickson, 1993). Fluctuation in $\mathrm{pH}$ value can stress marine organisms and may ultimately lead many species to leave the area or die.

The results of transparency measurements in the Tanah Merah Waters had an average value range of 0.09-1.20 m, while those in the Semujur Island Waters had an average value range of 3.90$5.90 \mathrm{~m}$ (Table 3.). According to statistica test, there is difference the mean of transparency value between the Tanah Merah Waters and the Semujur Island Water (Table 4.).

As we know, turbidity is a measure of light scattering caused mainly by suspended sediment, microalgae, microorganisms and other particulate matter in the seawater column (Macdonald et al., 2013). Based on the results of turbidity measurements in June, July and August 2018, the results showed that Tanah Merah Waters had an average value range of 12.2-22.5 NTU and in 
Semujur Island Waters were 3.60-7.80 NTU (Table 3.). There is statistically difference the mean of turbidity between the Tanah Merah Waters and the Semujur Island Waters. The average value of turbidity in the Tanah Merah waters was higher than in the Semujur Island Waters. This proves that the higher the turbidity value the higher the level of pollution in a waters (Jones et al., 2015). The turbidity value in the Tanah Merah Waters is still the same compared to the research results (Jones et al., 2015) which show that the mean turbidity for Barrow Island, Café lambert and Burrup Peninsula, Australia had value range 3 - 5 NTU. The value of turbidity can be gave effect on Total Suspended Solid (TSS). Total suspended solid (TSS) and turbidity is one of the important indicators that could be determining the quality of the seawater. The greater the turbidity value, the greater the TSS value in a water.

In the Semujur Island Waters, the highest mean TSS (Total Suspended Solid) values were found at stations 2 and 3 (15.8 and 16.2 mg.t-1) (Table 3.). Statistical results show there is no significant difference the mean value of TSS between Tanah Merah Waters and Semujur Island Waters. (t-test one tail; t count $=0.177$; $d f=5$; $P=$ 0.05) (Table 4.). Based on measurements in the Tanah Merah Waters, the average nitrate concentration was 0.15-0.18 mg.L-1 (Table 3). Meanwhile, in the Semujur Island Waters had range 0.14-0.33 mg. $\mathrm{L}^{-1}$. The highest nitrate concentration was found in Station 1 in the Semujur Island Waters (0.33 $\left.\mathrm{mg} . \mathrm{L}^{-1}\right)$. This indicates that there is nutrient enrichment that causes phytoplankton growth. The range of nitrate in natural waters is between 0.010.7 mg.L-1 and nitrate levels in natural waters are almost never more than $0.1 \mathrm{mg} . \mathrm{L}^{-1}$, but if the nitrate level is greater than $0.2 \mathrm{mg} . \mathrm{L}^{-1}$, it will result in eutrophication (enrichment) which further stimulates the rapid growth of algae and water plants. (Gypens et al., 2009). However, based on analysis statistic, there is no significant difference the mean value of nitrate between the Tanah Merah Waters and the Semujur Island Waters. (t-test one tail; $t$ count $0.753 ; \mathrm{df}=5 ; \mathrm{P}=0.05)$ (Table 4).

Table 2. Average of Abundance of Phytoplankton (cells. L-1) $^{-1}$ in the Semujur Island Waters

\begin{tabular}{cccccccc}
\hline \multirow{2}{*}{ No } & \multirow{2}{*}{ Genus } & \multicolumn{5}{c}{ Station in Semujur Island Waters } \\
\cline { 3 - 7 } & & 1 & 2 & 3 & 4 & 5 & 6 \\
\hline 1 & Skeletonema & 4,000 & - & 8,000 & 8,000 & - & 12,000 \\
2 & Melosira & 16,000 & - & 8,000 & 10,000 & - & - \\
3 & Coscinodiscus & 8,000 & 8,000 & 12,000 & 8,000 & 8,000 & 8,000 \\
4 & Rhizosolenia & 8,000 & 8,000 & 16,000 & 12,000 & 12,000 & 16,000 \\
5 & Bacteriastrum & 12,000 & 12,000 & 8,000 & 8,000 & 8,000 & 10,000 \\
6 & Chaetoceros & 56,000 & 68,000 & 60,000 & 56,000 & 80,000 & 56,000 \\
7 & Biddulphia & 8,000 & 8,000 & 12,000 & 12,000 & 8,000 & 8,000 \\
8 & Leptocylindrus & 8,000 & 8,000 & 12,000 & 12,000 & 4,000 & 4,000 \\
9 & Thalasiothrix & 64,000 & 88,000 & 72,000 & 96,000 & 60,000 & 64,000 \\
10 & Thalasionema & 40,000 & 44,000 & 44,000 & 36000 & 56,000 & 44,000 \\
11 & Pleurosigma & - & - & - & - & - & - \\
12 & Nitzschia & 24,000 & 24,000 & 16,000 & 16,000 & 20,000 & 24,000 \\
13 & Noctiluca & 8,000 & 8,000 & 4,000 & 4,000 & 4,000 & 4,000 \\
14 & Ceratium & 32,000 & 36,000 & 44,000 & 40,000 & 36,000 & 36,000 \\
\hline
\end{tabular}

Table 3. The Value Average of Water Quality from June, July and August 2018 at Tanah Merah Waters and Semujur Island.

\begin{tabular}{|c|c|c|c|c|c|c|c|c|c|}
\hline Location & $\begin{array}{c}\text { Temperature } \\
\left({ }^{\circ} \mathrm{C}\right)\end{array}$ & $\begin{array}{l}\text { Salinity } \\
\text { (ppt) }\end{array}$ & $\mathrm{pH}$ & $\begin{array}{c}\text { Transparancy } \\
(\mathrm{m})\end{array}$ & $\begin{array}{c}\mathrm{DO} \\
(\mathrm{ppm})\end{array}$ & $\begin{array}{c}\text { Nitrate } \\
(\mathrm{ppm})\end{array}$ & $\begin{array}{c}\text { Phosphate } \\
\text { (ppm) }\end{array}$ & $\begin{array}{c}\text { Turbidity } \\
\text { (NTU) }\end{array}$ & $\begin{array}{c}\text { TSS } \\
\text { (mg.L-1) }\end{array}$ \\
\hline \multicolumn{10}{|c|}{ Tanah Merah } \\
\hline 1 & 31 & 31.00 & 8.27 & 0.76 & 6.60 & 0.15 & 0.03 & 19.5 & 11.8 \\
\hline 2 & 31 & 34.00 & 8.23 & 0.09 & 6.63 & 0.16 & 0.05 & 22.5 & 8.2 \\
\hline 3 & 31 & 35.00 & 8.30 & 1.20 & 6.89 & 0.16 & 0.03 & 15 & 6.9 \\
\hline 4 & 31 & 34.00 & 8.21 & 0.09 & 6.70 & 0.16 & 0.04 & 14.9 & 9.8 \\
\hline 5 & 31 & 32.00 & 8.30 & 1.10 & 6.54 & 0.17 & 0.03 & 12.2 & 7.6 \\
\hline 6 & 31 & 32.00 & 8.23 & 1.20 & 6.79 & 0.18 & 0.02 & 12.5 & 6.8 \\
\hline \multicolumn{10}{|c|}{ Semujur Island } \\
\hline 1 & 30 & 33.00 & 8.32 & 5.00 & 6.87 & 0.33 & 0.01 & 4.82 & 3.8 \\
\hline 2 & 31 & 35.00 & 8.36 & 4.00 & 6.89 & 0.14 & 0.02 & 7.8 & 15.8 \\
\hline 3 & 30 & 37.00 & 8.39 & 4.60 & 6.92 & 0.15 & 0.02 & 4.14 & 16.2 \\
\hline 4 & 30 & 35.00 & 8.31 & 5.90 & 6.96 & 0.13 & 0.02 & 7.22 & 5.2 \\
\hline 5 & 31 & 33.00 & 8.36 & 4.90 & 6.89 & 0.14 & 0.02 & 3.6 & 3.8 \\
\hline 6 & 30 & 35.00 & 8.36 & 3.90 & 6.94 & 0.14 & 0.01 & 4.88 & 3.2 \\
\hline
\end{tabular}


Table 4. The result of statistic analysis water quality parameter between Tanah Merah Waters and Semujur Island Waters

\begin{tabular}{ll}
\hline Water Quality Parameter & Statistic analysis $t$-test one-tail $; \mathrm{df}=5 ; P=0.05$ \\
\hline Temperature & $\mathrm{t}$ count $=3.162 ;$ Different significant \\
Salinity & $\mathrm{t}$ count $=5.000 ;$ Different significant \\
DO & $\mathrm{t}$ count $=4.788 ;$ Different significant \\
pH & $\mathrm{t}$ count $=6.751 ;$ Different significant \\
Tranparancy & $\mathrm{t}$ count $=9.348 ;$ Different significant \\
Turbidity & $\mathrm{t}$ count $=7.904 ;$ Different significant \\
Nitrate & $\mathrm{t}$ count $=0.753 ;$ No different significant \\
Phosphate & $\mathrm{t}$ count $=5.000 ;$ Different significant \\
TSS & $\mathrm{t}$ count $=0.177 ;$ No different significant \\
\hline
\end{tabular}

Phosphate and Nitrate are essential nutrients for marine plant in the marine ecosystem. All living marine organisms require the nutrients nitrogen and phosphorus for their growth, metabolism and reproduction. Additionally, nitrogen is a component of amino acids, nucleic acids and other cell components, while phosphorus is found primarily in nucleic acids, phospholipids and adenosine triphosphate (ATP) (Patey et al., 2008).

There is statistically difference the mean of phosphate value between the Tanah Merah Water and the Semujur Island Water (one tail t-test; tcount $=5,000 ; \mathrm{df}=5 ; \mathrm{P}=0.05$ ) (Table 4.). The high phosphate content at the Tanah Merah Waters (0.02-0.05 mg. $\left.\mathrm{L}^{-1}\right)$ is thought to be because this station is close to the coastal tin mining location. This area gets a flow of nutrients from the land in the form of sediment flow or sediment from rivers or land when it rains, and also from the results of human activities. Apart from this, the stirring process at the bottom of the waters and the circulation process from the surface will greatly affect the amount of phosphate content. Meanwhile, on the Semujur Island Waters, which is far from the mainland, has a lower phosphate content (0.01-0.02 mg. $\left.\mathrm{L}^{-1}\right)$. The low concentration of phosphate in the Semujur Island Waters is due to the utilization by phytoplankton, therefore the average phytoplankton abundance value in the Semujur Island Waters is higher than the Tanah Merah Waters. Patey et al. (2008) stated that the phosphorus content is generally declining further and further out to sea (off shore). In coastal waters and continental shelves, mining activities and land flows will carry carried away waste, tailings, and other inland phosphate sources and result in greater concentration from the surroundings.

\section{Conclusion}

The average abundance of phytoplankton in Semujur Island Waters (286,000-318,000 cells.L-1) is higher than Tanah Merah Waters (188,000200,000 cells. $\left.L^{-1}\right)$. The magnitude of the abundance value in the Semujur Island Waters is also followed by the large average value of the diversity index and the low average value of the dominance index. However, the evenness index for both waters is included in the medium category. In the Semujur Island Waters, Diatoms (Thalassiothrix, Chaetoceros and Thalassionema) are more dominant than the Dinophyceae group. Whereas in the Tanah Merah Waters, the genera Ceratium belong to class Dinophyceae was more dominant than the class Bacillariophyceae. The influence of tin mining on the Tanah Merah Waters results in a lower average value of phytoplankton abundance compared to the Semujur Island Waters, where is far from the tin mining area. The magnitude of the concentration of Phosphate, nitrate, DO, pH, transparency and salinity in the Semujur Island Waters is compared to the Tanah Merah Waters, which results in the large average value of phytoplankton abundance in Semujur Island Waters. On the contrary, the average value of turbidity and Total Suspended Solid in Tanah Merah Waters can cause low abundance of phytoplankton. It can be concluded that tin mining can disrupt the abundance and composition of phytoplankton as a primary producer of waters.

\section{References}

Dickson, A.G. 1993. The Measurement of seawater pH. Mar. Chem. 44:131-142. doi: 10.1016/ 0304-4203(93)90198-W

Fachrul, M.F., Haeruman, H. \& Sitepu, L.C. 2005. Komunitas Fitoplankton Sebagai Bio-Indokator Kualitas Perairan Teluk Jakarta, Proceeding Seminar Nasional MIPA UI, Fakultas MIPA Universitas Indonesia, Depok. 25-26 November 2005.

Gypens, N., Borges, A.V. \& Lancelot, C. 2009. Effect of eutrophication on air-sea $\mathrm{CO} 2$ fluxes in the coastal Southern North Sea: a model study of the past 50 years. Global Change Biology, 15:1040-1056. doi: 10.1111/j.1365-2486.20 08.01773.x

Haya, L.O.M.Y. 2012. Distribution Patterns of Phosphate and Nitrate and Relation to Development of Seaweed farming In North Moramo Waters. J. Fish. Mar. Sci., 1(2):24-32. 
Jones, R., Fisher, R., Stark, C. \& Ridd, P. 2015. Temporal Patterns in Seawater Quality from Dredging in Tropical Environments. Plos One. 10(10):e0137112. doi: 10.1371/journal.pone. 0137112.

Lee, G.F. \& Jones-Lee, A. 2005. Eutrophication (excessive fertilization). Water Encyclopedia, 3:107-114. doi: 10.1002/047147844X.sw1606

Macdonald, R.K., Ridd, P.V., Whinney, J,C., Larcombe, P. \& Neil, D.T. 2013. Towards Environmental Management of Water Turbidity Within Open Coastal Waters of The Great Barrier Reef. Mar. Poll. Bull., 72:82-94. doi: 10.1016/j.marpolbul.2013.07.026PMID:2394 8091.

Millero, F.S. \& Sohn, M.L. 1992. Chemical Oceanography. CRC Press. London

Nguyen, G.T. \& Nhien, H.T.H. 2020. PhytoplanktonWater Quality Relationship in Water Bodies in the Mekong Delta, Vietnam. App. Environ. Res., 42(2):1-12. doi: 10.35762/AER.2020.42.2.1

Odum, W.E. 1988. Comparative ecology of tidal freshwater and salt marshes. Ann. Rev. Ecol. Sys., 19(1):147-176. doi: 10.35762/AER.2020.4 2.2.1.

Patey, M.D., Rijkenberg, M.J.A., Statham, P.J., Stinchcombe, M.C., Achterberg, E.P. \& Mowlem, M. 2008. Determination of nitrate and phosphate in seawater at nanomolar concentrations. Trends in Anal. Chem., 27(2): 169-182. doi: 10.1016/j.trac.2007.12.006

Reynolds, C., Huszar, V., Kruk, C., Naselli-Flores, L. \& Melo, S. 2002. Towards a functional classification of the freshwater phytoplankton. J. Plankton. Res. 24:417-428. doi: 10.1093/ plankt/24.5.417
Rachman, A. 2019. Phytoplankton Community Structure in the Waters Around The Coastal Tin Mining of West Bangka. J. Teknol. Ling., 20(2): 189-203. doi: 10.29122/jtl.v20i2.2938

Spatharis, S. \& Tsirtsis, G. 2010. Ecological Quality Scales Based on Phytoplankton for the Implementation of Water Framework Directive in the Eastern Mediterranean. Ecol. Indicat., 10(4):840-847. doi: 10.1016/j.ecolind.2010.01. 005

Tomas, C.R. 1997. Identifying Marine Phytoplankton. Academic Press. San Diego. California. USA. 858

Troccoli, G.L., Herrera-Silveira, J.A. \& Comı 'n, F.A. 2004. Structuralvariations of phytoplankton in the coastal seas of Yucatan, Mexico. Hydrobiologia, 519: 85-102. doi: 10.1023/B: HYDR.0000026487.78497.b6

Widianingsih, R. Hartati, A. Djamali \& Sugestiningsih. 2007. Abundant and Horizontal Distribution of Phytoplankton at East Coastal Belitung Island Waters. IImu Kelautan: Indonesian Journal of Marine Science, 12(1): 6-11.

Yamaji, I. 1979. Illustrations of the Marine Plankton of Japan. Hoikusha. Publisher: Hoikusha, Japan.

Zaghloul, F.A.R., Khairy, H.M., \& Hussein, N.R. 2020. Assessment of phytoplankton community structure and water quality in the Eastern Harbor of Alexandria, Egypt. Egypt. J. Aqua. Res., 46(2):145-151. doi: 10.1016/j.ejar.2019. 11.008

Zuur, A.F., leno, E.N., Walker, N.J., Saveliev, A.A., \& Smith, G.M. 2009. Mixed effects models and extensions in ecology with R. Springer.71-100. doi: 10.1007/978-0-387-87458-6_4. 